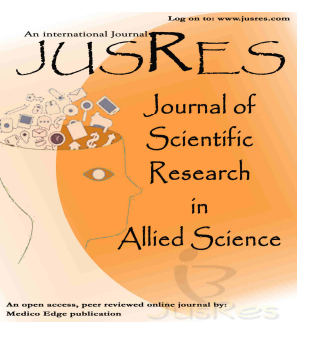

ISSN No. 2455-5800

Journal of Scientific Research in Allied Sciences

\title{
RISE OF WOMEN EMPLOYMENT IN PUBLIC RELATIONS PROFESSION: A PRACTICAL OVERVIEW IN RELATION TO INDIAN PR AGENCIES: REASONS, SCOPE \& CHALLENGES
}

\author{
*Dr. Tanushri Mukherjee, **Ms. Muskan Baijal \\ *Associate Professor, Amity School of Communication, Amity University Rajasthan, Kant \\ Kalwar, NH No-11C, Jaipur, Rajasthan, India \\ **Communications Manager, GRRAS Solutions Pvt. Ltd., Jaipur
}

Article history:

Submitted on: October 2017

Accepted on: October 2017

Email: info@jusres.com

\begin{abstract}
In the present times when we talk of gender equality, women empowerment and women liberation, the growing number of successful women professionals working in various professions around the world act as sufficient testimonials of it. The ever changing and dynamic profession of Public Relations is also not an exception to this latest trend. PR has emerged as a field where we find a good number of apt examples of efficient and experienced women professionals who have been able to create a mark for themselves in the field. Today the industry employs a large number of skilled women professionals who are performing very well in the industry at par with the men counterparts and their inborn traits, attitude and self confidence have proved out to be very significant factors contributing in making them more deserving and suitable for the field.

The paper explores the various aspects of the reasons behind the growing trend of recruiting women in the profession. In order to make the study more authentic, the paper tries to find out the perception of some of the successful women employees working in some of the very reputed PR Agencies and tries to study their opinion regarding the reasons behind the growing number of women employees in PR profession and also what gives them immense job satisfaction in the field.
\end{abstract}

KEYWORDS: Profession, Trends, Women, Professionals, Recruiting, Reasons. 
"Rise of women employment in public relations profession: A practical overview in relation to Indian PR

\section{INTRODUCTION} agencies: Reasons, scope \& challenges"

\section{CORE OF PUBLIC RELATIONS}

Public Relations is the art and science of making people, government and organization look good. This industry is all about managing reputation capital. Reputation capital is the kind of a goodwill a company possesses in the market for a long period of time. PR is all about eighty percent behavior and relationship building and twenty percent communication. The commonly accepted definition of PR is that it is a management function which evaluates public attitudes, identifies policies and procedures of an individual or an organization with public interest and plans and executes a program of action to earn public understanding and goodwill. This industry is all about influencing the behavior to achieve objectives through effective management of relationships and communications.

This industry has witnessed remarkable growth and advancement in the past few years in India. It is growing due to the increasing need for brand positioning and reputation building in the business industry. The major reasons for the growth of this industry can be as follows:

- Growth in the business sector and emergence of big corporate organizations

- Increasing importance of public opinion

- Growth of media

- Need for prompt and accurate internal and external communication

- Growth in economy

- Liberalization and globalization

- Growth in democracy

- Fierce business competition and the need for creating strong relations with stakeholders to create a strong and safe place in the market

The doubts regarding the growing magnitudes of PR industry have been proved to be wrong due to the successful functioning of few leading PR Agencies in India namely Adfactors PR, Edelman, Hanmer MS\&L, Genesis PR, Weber Shandwick, Oglivy PR, Perfect Relations There's much more truth to the old myth that public relations is "fostering and feeding of the reporters." The essence of public relations has become very widespread and chiefly consists of informing and persuading the publics or concerned stakeholder groups and not just one person at a time, but reaching out to masses through various means of mass communication like newspapers, radio, television and the web. People like political leaders, professionals, actors, rock stars, celebrities, corporate organizations, various service as well as manufacturing sector organizations, all require public 
"Rise of women employment in public relations profession: A practical overview in relation to Indian PR agencies: Reasons, scope \& challenges"

relations to handle their daily need of information dissemination, vast array of communication as well as handling media enquiries and relations.

Public Relations is different from marketing as marketing is about getting people buy something, whereas public relations has lot more to it. It manages not only media relations but also takes care of investors relations, stakeholders, customers, employees, community relations as well as human resource management through the application of multi- media PR Strategies and Tools.

\section{NEW EMERGING TRENDS IN PR PROFESSION}

With the emerging trends in the society the traditional PR tools have been replaced by new tools in the market. Public Relations is immensely growing at a fast pace as the media business is changing. Newspapers, radios, TV, all of them are trickling around where each of them is trying to fit at the pinnacle of the market. Handy information is the new need of the town. Smart Phones are replacing all other communication tools because time is precious in this century and people know how to utilize it efficiently by just getting whatever information one desires for at their finger tips. Today's youth are the consumers of varied types of innovative ideas, news and information and because of their changing demands and expectations, the entire process of news gathering and dissemination, channels of communication, advertising as well as the function of Public Relations is also pacing faster and the advent of Digital Media has further more contributed to the trend.

As described by Mukherjee, T. (2012), "Today if you ask a practitioner to define the field, the likely response is a list of the activities that are included under the jurisdiction of public relations: publicity, advertising, event management, media relations, employee relations, shareholder relations, customer and community relations, image branding, crisis management and so on".

Pointing out towards the immensely increasing significance of the discipline of Public Relations, Mukherjee, T. (2017) states that, "There has been a great growth in the practice of Public Relations activities in our country and abroad in the recent decades. Changing business trends and practices, fierce cut-throat competition on the one hand and media explosion on the other hand as well as the growing significance of public opinion and public participation resulting in the emerging significance of Value Co-Creation have made almost all business enterprises no matter whether public or private realize the importance of two-way communication practice, public involvement and participation and two-way mutual understanding and relationship building with its internal and external public". 
"Rise of women employment in public relations profession: A practical overview in relation to Indian PR agencies: Reasons, scope \& challenges"

\section{ROLE OF DIGITAL MEDIA BEHIND ENCOURAGING WOMEN EMPLOYMENT IN PUBLIC RELATIONS}

Social Media is becoming a prominent platform and is replacing the traditional media day by day with its new trend of creating a participatory and interactive communication culture. It is becoming the most preferred vehicle of choice for many clients for launching their campaigns and making it successful. It is easily accessible and holds immense power in shaping public opinion across the world. As the intensity and volume of online communication increases, so does the number of women in India who are actively bracing up their opinions and views through social media as this platform continues to be one of the most widely used by women of present times. There are various reasons behind the increasing inclination towards Digital Media, which are described below:-

\section{- INCLINATION TOWARDS PORTABLE DEVICES}

The smart phones have enabled the young generation to get their work done with great ease as they can simply rely on their phones and do their work without even going anywhere or asking anyone.

\section{- SMART PHONES MADE THE NEWS HANDY AND EASILY AVAILABLE.}

Every information and details are just a click away with the easy access to mobile phone and internet. The internet and smart phone together have created miracle in the world and have served a great purpose for the masses by minimizing their efforts

\section{- ONE CAN GET ANYTHING OR EVERYTHING AT ONE SINGLE PLACE AND IT'S JUST A CLICK AWAY.}

One can respond almost instantly and avail anything or everything regardless the time and place and facility of instant feedback is readily available.

\section{- AGGRESSIVELY ACTIVATED NEWS AGGREGATORS}

We all have probably heard of popular sites for online sites like Huffington Post In working culture women often suffer from a fear of having to face the nasty consequences of being extremely outgoing in expressing their views openly in work place as they have a fear of becoming the most talked about topic of gossip among peers. Social media is able to break this fence as women feel more confident in expressing their views and opinions and are more expressive than men on this platform. Whether it's the question of sharing their opinion on certain controversial issues or staging their vehement opposition to certain socio-political policies or whether its expressing their personal stories about social or domestic atrocities. As rightly discussed by Mukherjee,T.(2015), “ In the present times, we find the widespread use 
"Rise of women employment in public relations profession: A practical overview in relation to Indian PR agencies: Reasons, scope \& challenges"

of blogs, social networking websites, twitter and smart phones as highly powerful and extremely influential platforms where issues related to women injustices and atrocities as well as violation of human rights, domestic violence and infringement of freedom of speech, thought and expression can be discussed or shared, thus contributing in building strong opinion groups or lobbyists with a very focused point of view and giving rise to people's movements". The sentences make it very clear that women have been making use of social media more rampantly and effectively for championing various causes and this skill of theirs have tended to make them most suitable and very successful in the PR profession as well because this is the field where social media has kept every other PR Tool lagging behind.

Women are better writers, capable of discharging multiple tasks quite well and are also better than men in socializing and building relations. This simply implies that they possess an edge over men in many aspects and in many tasks. They have overtaken the men counterparts in the field of social media by their ability to think and deliver faster and more efficiently and effectively over such platforms which are more spontaneous, innovative and interactive.

\section{REASONS BEHIND THE GROWTH OF WOMEN EMPLOYMENT IN PUBLIC RELATIONS}

The last 20 years record of the functioning of Public Relations industry has seen a rich incursion of women into this field. Women have been able to create and nurture new opportunities and roles for themselves, beyond the traditional image of theirs performing just certain stereotyped roles centered around working as either a teacher or a social worker or a nurse and above all just a house maker. It is in the context of this changing occupational dynamics regarding women that Public Relations is not an exception. This is the field which has embarked a sudden shift too and has witnessed an increase in women majority. Women make up 63 percent of public relations "specialists," according to Bureau of Labor Statistics data, and 59 percent of all PR managers. There are many reasons behind the success and growth of women in this industry. Few of them cited can be:

A Media portrait is a vivacious image of what consists of a female PR professional's life. In many movies the character played by certain actors paint an exotic picture of PR professional like one Samantha Jones of Sex and the city played by Kim Cattrall.

- This is a highly paid industry as compared to the related industry like journalism, print media, radio etc. 
"Rise of women employment in public relations profession: A practical overview in relation to Indian PR agencies: Reasons, scope \& challenges"

- Studies have shown that women are more creative, collaborative and prefer to work in teams as compared to men. Also they have a slightly higher convincing power than men have naturally.

- Women are known for their affinitive nature and this one skill is a must for a good PR professional. One must have the ability to understand other person's or organization's situation.

- It has been proclaimed that women are better than men at motivating, guiding employees and also appreciating and praising them thus helping in the building of satisfactory employee relations.

Women have the tendency to be bent towards arts and men towards science. Therefore women have more artistic characteristics than men including their writing skills, which is an essential professional skill required in Public Relations Industry.

- It has been purported that women are better in engaging and facilitating conversations than men. They are more communicative as well as good listeners in comparison to men and it is this skill which keeps them more in demand than men folk.

- Gemma Craven of Ogilvy said in the video interview that women are better multi-tasker than men and PR being a profession which is based on heavy multi-tasked environment.

Most people are not properly aware of the contribution made by the Public Relations industry for working women in India. In the present times this industry employs many women which has further motivated many more to enter the industry. The profession of PR is all about filtered gossip and publicity and women are considered to be the best when it comes to this task as well. Women are experts in narrating stories in their normal routine lives which is a synonymous quality accepted in the PR profession too.

According to human psychology, women tend to possess natural traits which compliments the PR industry fairly well. Be it writing a press release, or making a media pitch or communicating convincingly and authentically with the stakeholders, client or media. All these functions entail efficient story telling and as discussed above women are good storytellers. PR calls for affinity in understanding situations, multi-tasking, creativity, narration and these skills are present in almost every women naturally.

\section{SCOPE OF WOMEN DEVELOPMENT}

Women have always outnumbered men whenever it comes to communication and this industry is all about possessing excellent communication skills thus paving the way for women emerging as leading work force in the PR industry. Studies have shown that 85 per 
"Rise of women employment in public relations profession: A practical overview in relation to Indian PR agencies: Reasons, scope \& challenges"

cent of the industry and 75 per cent of the members of PRSI (Public Relations Society of India) comprises of women which clearly indicates the evolution of women in this area. PR is also about relationship management be it with clients, public, stakeholders or media. Women have emerged to be better relationship managers and are more concerned about strengthening and nurturing ties in a much more better manner than men. This basic instinct and skill enables them to be more efficient in handling their organization's relationship as well with the clients, stakeholders, public and media and do not let them feel secluded or unattended during crisis situations contrary to men who are rather more focused about proving their competence in the profession and for whom relationship building measures is secondary.

According to a report by Makovsky, K.(2013), "In 2010 Ragan.com reported that $73 \%$ of the 21,000 members of PRSA were female. Another estimate, from the chair of the PR department at Syracuse University, put the percentage of women in the industry at $85 \% "$.

The nature of this industry is not constant, hence every PR agency choose their cards wisely in order to be at the top. Every organization is adapting new trends and strategies to acquire a competitive edge and to achieve this objective they are following a well decided recruitment strategy in the direction of choosing the best possible employees for their organization. PR Agency is no exception to the trend and have become very selective in recruiting expert professionals who have the natural traits and personal as well as professional skills which suits the profession.

Women are embarking their marks in almost all the sectors be it public or private, they've been setting examples for men and are marching ahead of them. We all have heard of Indira Nooyi (CEO, PepsiCo), Arundhati Bhattacharya (Chairman, SBI), Chanda Kocher( CEO, ICICI Bank), all these ladies have added feathers to the cap of women empowerment and have emerged as role model for millions. Women in the field of Public Relations are also achieving outstanding success and reaching out to the heights of excellence and pinnacle. Prema Sagar (Vice Chair, Burson-Marsteller, Asia Pacific \& Principal/Founder, Genesis Burson-Marsteller) is considered the queen of PR in India and is recognized as one of the most experienced PR professional in the country. As rightly described in the website of Burson- Marsteller, "Prema has been named by PRWeek among the most influential PR professionals as part of the Global Power Book 2016. She was named among the 50 most influential people in PR in their Asia Poweuuu u./r List 2014 and by the Impact magazine among the 50 most influential women in India in the field of media, marketing and advertising for four consecutive years". Apart from Prema 
"Rise of women employment in public relations profession: A practical overview in relation to Indian PR agencies: Reasons, scope \& challenges"

Sagar few more names including: Valerie Pinto (Chief Executive Officer at Weber Shandwick India), Sunayna Malik (President, South Asia, Hill+Knowlton Strategies), Nandita Lakshmanan ( Founder \& Chairperson, The Practice) have played a pivotal role in adding name to the PR profession and are testimonials of successful women working as PR Industry veterans with rich experience.

When it comes to those industries which have given employed women an opportunity to show their real worth to the world, then there are two leading communication industries where we come across a good number of faces of successful women professionals. These are in the field of Television Journalism and Public Relations where women have performed exemplary well and have been great achievers. As rightly given in the site PRmoment.in (2014), "Shravani Dang, Vice President and Global Group Head of Corporate Communications at Avantha Group and Advisory Board member of Women in Leadership Forum and who has spent over 22 years in PR feels that, "PR calls for empathy in understanding situations, multitasking and creativity - these are skills that are inherent in women - and using these skills help deliver best results."

(Quoted from :- http://reputationtoday.in/features/indias-top-10-women-in-public-relations/)

\section{LITERATURE REVIEW}

According to a blog mentioned in a site www.vitispr.com it is clearly said that "The area of Public Relation market has evolved from male dominant to predominantly female profession". Also according to a blog written by Olga Khazan Why are there so many women in Public Relations, it has been clearly stated that nearly two-thirds of the industry comprises of women professional.

In a book Women in Public Relations by Larrisa A. Grunig Elizabeth, Lance Toth, Linda Childers Hon, foreword by Kathleen Larey Lewton and they integrate the theoretical literature of public relations and gender with the findings of the largest longitudinal study on the women in the field of public relations. This study not only focuses on the scope and development but also the gender inequality and biasness faced by women in terms of salary, ascension and managerial ranks. The Board of Directors of PRSA (Public Relations Society of America) has given statement on equality of opportunity affirming equal opportunity and compensation of women professional in the industry. It also highlights the development of strategies and layouts to overcome the sex bigotry in public relations.

Another major observation of the co-author during her volunteering experience in the internationally acclaimed and extremely popular Jaipur Literature Festival of 2016 was that the media delegate team who was responsible for managing the social webpage and other 
"Rise of women employment in public relations profession: A practical overview in relation to Indian PR agencies: Reasons, scope \& challenges"

online activities included more female staff than male. The delegation was authorized to Edelman Group whose team majorly from Mumbai and Pune were designated with the work. From the observation it can be concluded that women are slowly-slowly occupying a major place in the PR Industry

According to a major article by Jainudeen, R.(2012) where he describes about his experience of joining the industry by commenting that there are far more women than men working as PR Practitioners and somewhere the cultural bias is responsible for such practice in Asia specially as it is commonly believed that a job in PR is better suited for women as probably many of the PR functions require soft skills such as communication, listening and negotiating which are better suited for women professionals. The more revealing aspect stated by the author was that after 20 years, it proves out to be a big challenge for him to recruit men to join his team. The lines further more strengthen the significance of the topic and support it with field based information. He further states that women are specially leading in PR Agencies in the communication team and all prominent PR Agencies are led by women.

A write up which presents some major facts about the present scenario of rising women power in PR is by womeninpr,(2012). The article states that in an industry once dominated by men, women now outnumber their male colleagues. Women have been successful to a great extent in making their mark in the PR Industry over the last 20 years to such an extent that there is nowadays a major shortage of men coming in the profession and the site further states that according to the latest membership figures released by the Institute of Public Relations (IPR), "Women now outnumber men by 60:40- a massive swing since 1987, when figures highlighted the opposite at 20:80".

\section{OBJECTIVES OF THE STUDY}

\section{FOLLOWING WERE THE OBJECTIVES BEHIND THE STUDY:}

- To develop an overview about the reasons behind the growing number of women employees in PR profession and their present status in the industry and future prospects.

- To develop an understanding about the various functions which are successfully carried out by women employees working in PR agency and in which they are far more better than their male counterpart.

- To explore the skills and attributes that women posses which helps them typically in the PR profession and which makes them very suitable for the field thus contributing towards their growth and enhancing their potential. 
"Rise of women employment in public relations profession: A practical overview in relation to Indian PR agencies: Reasons, scope \& challenges"

- To develop a deeper insight into the relevance of the topic by collecting Primary Data from women professionals working in leading PR Agencies.

\section{SIGNIFICANCE OF THE STUDY}

The topic of the study is highly significant, very new, interesting as well as contemporary as it adds to the knowledge base related with the workforce of the PR industry. In the present times when we talk of women empowerment and gender justice and gender equality, the topic assumes much significance as the study explores a very interesting fact related with the ever evolving PR Industry and arrives at a conclusion which is highly enlightening as it reveals the increasing importance of women in the PR profession and the reasons behind this trend. The study becomes very significant because along with the growing public discourse on women empowerment, it focuses on what has been the trend in the PR Industry and how similarly one can even witness the impact of women empowerment even in the field of PR.

The significance of the study is also the fact that very few studies have been done in this area.

\section{RESEARCH METHODOLOGY}

The study employs both Secondary as well as Primary Data Collection Methods. In order to make the study primary data- based, it seeks the opinion of some of the leading PR professionals who have been in this industry for quite a long time. The study conducts a practical field based study of three leading PR Agencies and studies the perception and opinion of PR Practitioners of the agencies regarding the issue through interviews. Interview was taken of 20 PR respondents as per their choice and convenience. Respondents selected for the study were first of all women PR professionals and above all those who were willing as well as prepared to speak on the topic, thus employing Purposive Sampling Method

As a part of secondary data collection, the paper makes an exhaustive study of various online articles and existing literature related to the growing trend of increasing women employment in PR profession.

\section{SAMPLE DESIGN}

The study collected Primary Data by interviewing and interacting with 20 women PR professionals working in top three Indian PR Agencies, namely Adfactors, Avian Media and Galvanise PR. Most of the respondents occupied significant positions as either owner of the agency or Account Director or Account Manager or Executive.

\section{BRIEF PROFILE OF SELECTED PR AGENCIES}


"Rise of women employment in public relations profession: A practical overview in relation to Indian PR agencies: Reasons, scope \& challenges"

\section{AVIAN MEDIA:-}

Founded by Nikhil Khanna, the company started off with just one client Airbus and gradually grew with having more than 65 clients being handled by more than 150 employees working at 6 offices. Business-driven communications is the motto of the company and they believe in conceptualizing, building and implementing effective and timely communication. One of the authors got the opportunity to interview some of the experienced women PR professionals of the agency after seeking appointment from them and finally the questionnaire was sent via mail and other necessary data was collected through phone.

\section{GALVANISE PR:-}

This PR consultancy firm was founded in March 2008 by Shalini Singh, a Bangalore based PR industry veteran. The creative team works in striving to achieve excellence in client servicing and understanding client's business. Their expertise lies in various sectors including healthcare, life sciences and technology space.

Shalini Singh pioneered the PR skills and sets a perfect example for an ideal PR woman and showcases excellent qualities of a PR person. Being the founder of the company, she helped the author in providing contact details of her staff and other female employees and as an end result of her efforts data was collected via email and phone.

\section{ADFACTORS PR:-}

One of the best PR agencies in India and the organization where the co-author got the opportunity to work as an intern and that helped further more to gather authentic information related to the subject. The top authorities of the company ensure that the motto of the company "Knowledge Driven Communication" is rigidly imbibed and followed by each and every employee of the organization in every work of theirs and in every walk of their life. The company has 14 offices pan India and also handles overseas PR through their offices in Dubai, Sri Lanka and US.

Adfactors PR Mumbai was the company where the co-author also got the opportunity to do her internship which immensely helped her to personally observe the present trend and gather primary data. She was working in BFSI vertical and she had a relishing and memorable learning experience. The interactions she had with other women employees during her period of internship provided an in-depth and a wider understanding about the industry, the tools and tricks to be employed for a fruitful survival in the profession and above all the growing prospects of women growth and success in the field. 
Most of the respondents with whom interaction was done or who were interviewed were working as Account Executive, Account Manager or Account Director. Being an intern and as a result personally knowing all of them helped a lot in data collection. Thus the coauthor had personally interacted with everyone at the workplace to collect primary data.

(Source: $\quad$ http://www.adfactorspr.com/about-us.aspx; $\quad$ http://galvanisepr.com/; http://www.avian-media.com/)

FINDINGS AND ANALYSIS

Q1. Response to the question, "Please select the age group".

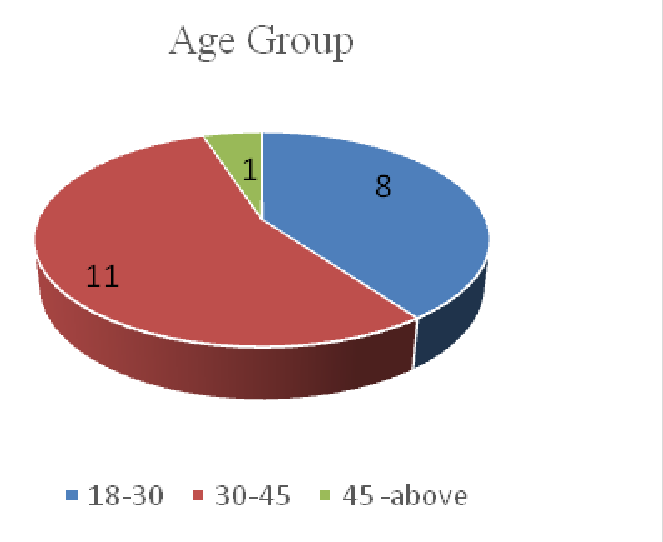

\section{FINDINGS AND INTERPRETATION}

- Out of 20 women PR professionals , 8 lie in the category of 18-30 years age group, 11 in the age group between 30-45 and 1 out of 20 woman fall in the age group 45 and above.

- The findings make it very clear that majority of women PR professionals are very young and they are highly skilled and expert in their area of work.

- The industry is highly dynamic and ever evolving and hence as a result there is sufficient scope for young and talented employees and young talented women are no longer lagging behind their men counterparts. 
"Rise of women employment in public relations profession: A practical overview in relation to Indian PR agencies: Reasons, scope \& challenges"

Q2. Response to the question, "Since how long you have been working in PR industry?"

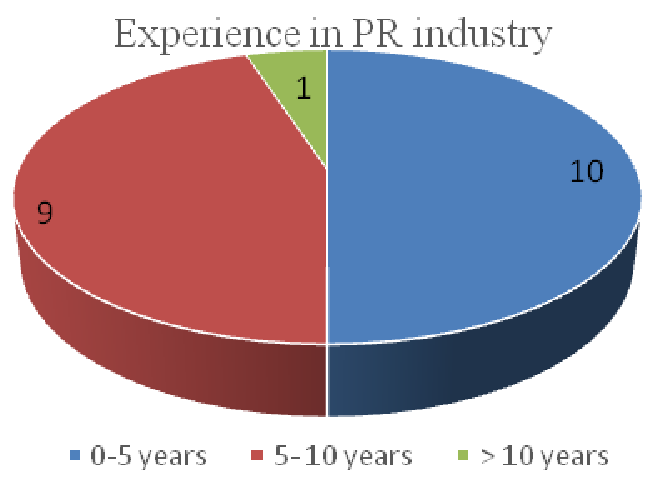

\section{FINDINGS AND INTERPRETATION}

- Response to the above question was that 10 women fall in the category of serving in the industry for about $0-5$ years. Out of 20 women, 9 women fall in the range of working as PR professional for about 5-10 years and just 1 woman fall in the range of 10 years and above.

- The responses clearly indicate that the profession highly demands young, talented and skilled employees and it is not necessary that you need to work for decades in an agency to be recognized in the field. The industry has become very competitive and has been adopting to new PR Strategies and Tools and young and hard working professionals who are acquainted with the techniques of the field and who possess background specialized knowledge and training can be the best choice.

\section{Q3. Response to the question, "Do you agree that this industry is female dominated?"}

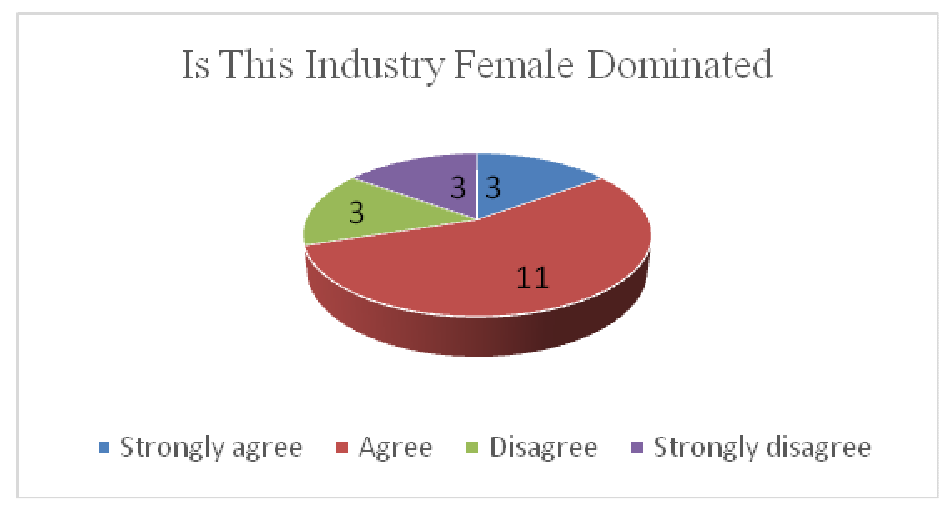

\section{FINDINGS AND INTERPRETATION}

- The response to the above question was very crucial as it was related with the final upholding of the topic or its rejection and revealed some major conclusions related with PR Industry. Out of 20 women respondents, 3 strongly agreed to the statement, 11 of them agreed, 3 women disagreed to the statement and 3 strongly disagreed. 
"Rise of women employment in public relations profession: A practical overview in relation to Indian PR agencies: Reasons, scope \& challenges"

- This data implies that majority of women believe that they have been able to create a space for themselves in this highly demanding and competitive industry despite of the patriarchal influence in the society.

- However some of them , 6 out of 20, still felt that there is some room for betterment as they either disagreed or strongly disagreed to the statement implying that they felt that there are equal number of male and female employees working in PR Agencies or there are more male PR professionals.

Q.4 Response to the question, "Do you feel women have more future prospects and chances of career growth in Public Relations Industry?"

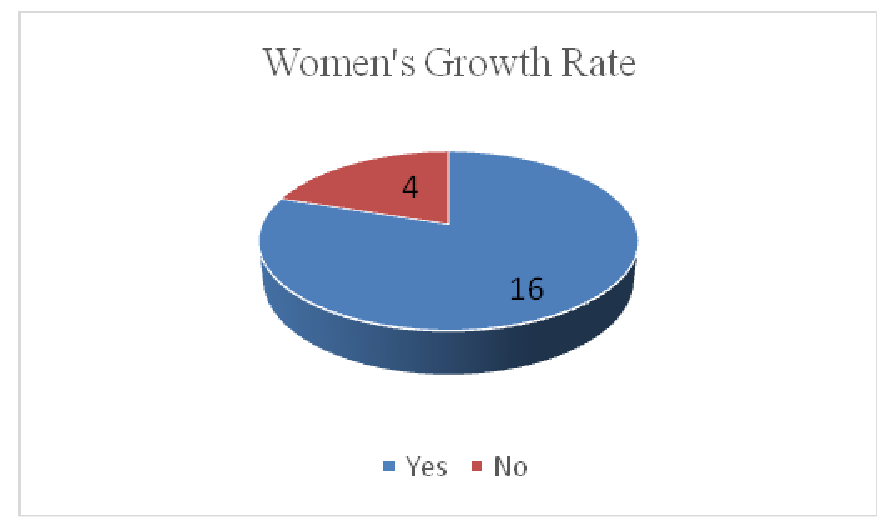

\section{FINDINGS AND INTERPRETATION}

- The topic of the study is very contemporary, new and interesting and has very strong implications for the PR industry as it explores the present situation as well as future prospects regarding women PR practitioners working in leading PR Agencies of India.

- 16 women PR professionals agreed to the above statement of women having good future prospects of career growth and development in the PR industry whereas 4 out of 20 respondents declined.

- It implies that majority of women believe that they have been successful in creating a mark for themselves in the industry and there are good chances of future job opportunities in this industry as well. More than half of the respondents, i.e $80 \%$ of them strongly opined that women PR professionals have emerged as strong players in the industry giving neck to neck competition to their male counterparts irrespective of any prevailing issues. 
"Rise of women employment in public relations profession: A practical overview in relation to Indian PR agencies: Reasons, scope \& challenges"

Q5. Response to the question, "Do you feel women possess certain skills and attributes which lead them towards success in the PR Industry?"

\section{Possession Of Skills and Attributes}

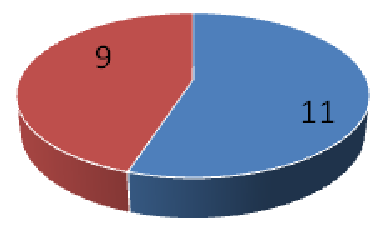

- Yes - No

\section{FINDINGS AND INTERPRETATION}

- The findings of the above question was highly awakening as it revealed as to how much are the women suitable for PR profession. 11 women respondents agreed to the statement that women possess certain skills and attributes which lead them to success in this industry whereas just 4 of them disagreed to the statement

- The findings and the data clearly establish the fact that it can be assumed that majority of women believe that they possess some natural traits and qualities which make them perfectly suitable for this industry and as a result they have been successful in giving much better results in the profession.

Q.6 Response to the question, "Do you feel nowadays that the number of women employees working in PR profession are equal in comparison to men?"

\section{Employment Ratio in terms with Men}

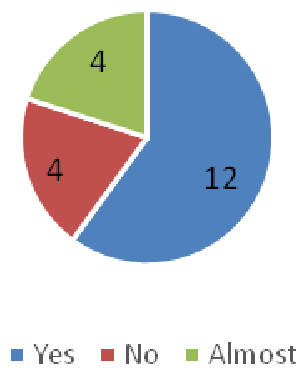

\section{FINDINGS AND INTERPRETATION}

- To make the study more significant and authentic it was necessary to explore the ratio of male and female employees working in PR profession. The results proved to be very 
"Rise of women employment in public relations profession: A practical overview in relation to Indian PR agencies: Reasons, scope \& challenges"

crucial as more than $50 \%$, i.e 12 women PR professionals thought that they are equal in terms of number in comparison with men in PR profession whereas only $20 \%$ percent i.e 4 women respondents strongly denied the statement stating that women have always outnumbered men in PR profession but that too pointed out that they strongly believed that women PR professionals are performing far better than men in the profession.

- Remaining 4 women respondents out of 20 expressed that they are almost equal in number in comparison to men. The responses were very much in support of the growing trend of more and more women moving into PR profession as almost a major number considered them to be equal in number to men and some were more enthusiastic and even considered the number of women choosing the PR profession to be greater than the number of men working in PR Agencies

\section{Q.7 Response to the question, "Do you feel women employees have been great achievers?"}

\section{Women are achievers}
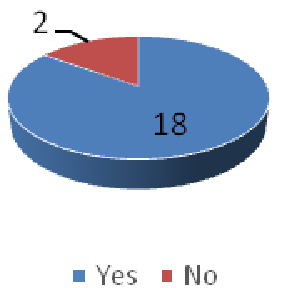

\section{FINDINGS AND INTERPRETATION}

The study was just not intended to find out the growing number of women PR professionals in the industry but it also aimed at exploring facts related to the growing career prospects of women in the field and to analyze the extent of success and satisfaction of women professionals associated with the industry.

The study with its primary data proved out to be very significant as it revealed the story of growth and development of women in the PR profession. Out of 20 women respondents 18 , i.e $90 \%$ of them believed that they have been strong achievers in this industry whereas just 2 of them thought that the best is yet to come which was again a positive indicator of the fact that there are all chances and scope for women achieving more in the profession and realizing their full potential and skills. 


\section{Q8. Response to the question, "Are you satisfied working in this profession?"}

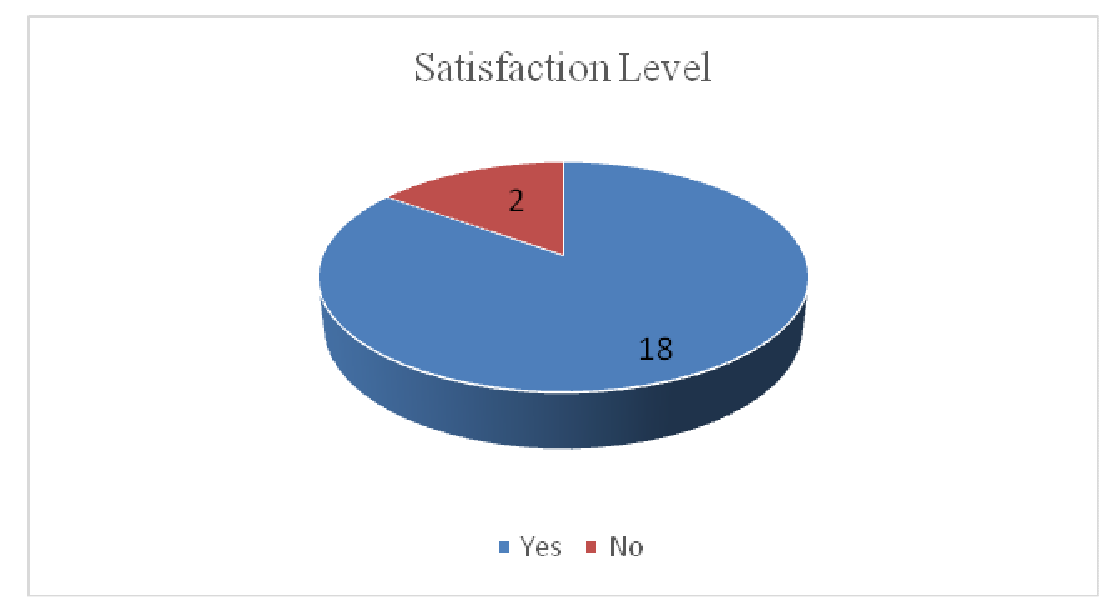

\section{FINDINGS AND INTERPRETATION}

- Besides finding out the number and the success percentage of women employees working in PR Agencies, the study also tried to find out the perception of women respondents regarding their satisfaction level in the profession.

- 18 women respondents working in PR Agencies expressed that they were highly satisfied with their profession whereas just 2 of them felt that one should never stay satisfied with their work as their always is a scope to explore and achieve more.

- The data clearly revealed that women are highly satisfied working in the PR profession as they see a huge amount of scope and avenues for future career growth for themselves in the profession and that has been the driving factor behind more and more women getting interested in PR profession and ultimately performing to the best of their efforts leading to job satisfaction.

\section{Q9. Response to the question, "Why are you interested in this profession?" FINDINGS AND INTERPRETATION}

Majority of the women strongly believed that this is the most challenging, creative, multi-dimensional and yet very demanding profession where they get to communicate stories to different audiences using different tools and strategies and it also provides a platform for them to grow and showcase their skills and traits in the best possible manner leading to their professional success and job satisfaction.

This profession also provides them an opportunity for networking with the top management officials of the company, maintaining relations with stakeholders and being socially active, enjoying a very demanding position in the organization. They also strongly 
"Rise of women employment in public relations profession: A practical overview in relation to Indian PR agencies: Reasons, scope \& challenges"

expressed that somewhere the women are naturally gifted with such qualities which are typically required in PR profession and which enables them to excel in the field and be highly motivated.

\section{Q10. Response to the question, "What encourages you to work in this profession?"}

\section{Findings and Interpretation}

Almost all the women respondents stated that this profession is the most different from other profession and challenging too as it always keeps them motivated to learn each day about various industries, brands and their new strategies and tactics to stay ahead in the fiercely competitive business environment . It opens the door for creativity, client interaction on a daily basis and at the same time presenting some never ending challenges and a passion to deal with them efficiently. These factors encourage and motivate them to contribute further more in the PR Profession

\section{LIMITATIONS}

- During the research process one of the major limitations which was faced was lack of availability of time and resources by the PR agencies

- Questionnaires had to be mailed to the agencies and they needed to be briefed about the whole research process, its relevance and their contribution, which was again a time consuming process.

- Regional PR agencies were also approached but due to unavailability of time they were not able to respond.

- As the questionnaire was given via e-mail, some people also found it difficult to understand its relevance and usage, which was later cleared through skype call interaction.

\section{CONCLUSION}

The overall learning outcome of this research helped to develop an understanding about the real picture regarding the position of women in Public Relations Industry, along with their exponential growth and scope of development in this field. The study helped a great deal in knowing the changed perception about the growing role of women in this field as compared to men and the reasons behind their increasing number, specially in PR Agencies.

The primary data collected by interacting with the women PR Practitioners employed in leading PR Agencies helped in developing a practical overview about the thoughts and ideas which the women have framed while working in the field.

Indian women have emerged as a strong team player and a multi-tasker in many ways contradictory to the earlier image of them as a weak and timid person undergoing various 
"Rise of women employment in public relations profession: A practical overview in relation to Indian PR agencies: Reasons, scope \& challenges"

societal pressures and gender exploitation. Though the battle for gender justice is still ongoing but the picture is not so gloomy

In the PR industry women have transpired and it is being observed that they are able to connect themselves with the industry far better than men as they find that they relate to it efficiently and are naturally born to serve this industry in the best possible manner. However, there have been various observations in this regard which states that there is still sufficient room left for improvement as it has also been seen that women still now have not been able to secure senior level management positions in the industry and they still face difference in terms of pay scale and power in regard to their male counterparts. Similarly there is also a great need for women developing an interest in learning various other skills of the profession besides just being satisfied with performing roles as technicians and adhering to a rigid system of gender stereotyped Public Relations discipline of women being just efficient communicators.(Broom \& Dozier, 1986).

Therefore the findings of the study are extremely crucial as it introduces the present scenario regarding women professionals working in PR Industry, specially in the top most super specialized PR Agencies and provides some valuable insight regarding the reasons behind their success ratio as well as their job satisfaction serving as successful PR professionals.

\section{REFERENCE}

- Avian Media: India PR Firm | Online PR agency | Delhi. (2014). Retrived from: http://www.avian-media.com/

- Alexander, L.(2016). INDIA’S TOP 10 Women in Public Relations Consulting. Retrived from http://reputationtoday.in/features/indias -top-10-women-in-public-relations/

- Adfactors PR. Retrived from : http://www.adfactorspr.com/home.aspx

- Broom, G.M. and Dozier, D.M.(1986). Advancement for public relations roles and models. Public Relations Review, (12) $1,37-56$.
- Galvanise PR. Retrived from: http://galvanisepr.com/

- Jainudeen, R.(2012). The Role of Women in the PR Industry. Weber Shandwick: Engaging always. Retrived from: webershandwick.asia> The- roleof-women.

- Khazan, o. (2014). The Atlantic. Why Are There So Many Women in Public Relations?. Retrived from: http://www.theatlantic.com/business/ar chive/2014/08/why-are-there-so-manywomen-in-pr/375693/ 
"Rise of women employment in public relations profession: A practical overview in relation to Indian PR agencies: Reasons, scope \& challenges"

- Larrisa A. Grunig., Elizabeth, Lance

Toth, Linda Childers Hon, foreword by

Kathleen Larey Lewton. (2013).

Women in Public Relations: How

gender influences practice. Routledge,

London

- Mukherjee, T.(2017). Role of PR in

Relations Management with Strategic

Partners leading to Value Co-Creation.

Handbook of Research on Strategic

Alliances and Value Co-Creation in the

Service Industry. IGI Global

- Mukherjee, T.( 2016). Role of Social

Media in Showcasing Women

Atrocities: A Study on Jaipur Youth.
Amity Journal of Media and

Communication Studies. Pg 32-41

- Mukherjee, T.(2012). Emerging

Trends in Public Relations : A Case

Study of the Strategic CSR

Perspective of HSBC Bank and its emergence as a strong Image Branding Tool. Amity Journal of Media and Communication Studies

- Womeninpr.(2012). Why Women Dominate PR Profession? Blog "Women in PR" at wordpress.com. Retrived from

https://womeninpr.wordpress.com 